\title{
Cost and Financing Higher Education by Nepalese Student in Australia, Student Loans and Role of Bank in Nepal
}

\author{
Kshitiz Upadhyay-Dhungel \\ M Phil student, Education Leadership, School of Education, Kathmandu University \\ Email: kistiz2008@gmail.com \\ Shreeram Lamichhane, PhD \\ Professor \& HOD, Education Leadership, School of Education, Kathmandu University
}

\begin{abstract}
In the last few decades, lots of youth have migrated to foreign lands from Nepal for their study. An estimated 20,000 students leave the country annually to pursue their further education abroad and a huge sum of more than NRs 2000 million outflows for this purpose. United Kingdom (UK), United States of America (USA), Australia are the preferred destinations of Nepalese students. In recent days, Australia has been found as the top destination for them. Currently, Nepal stands in the $6^{\text {th }}$ position in terms of number of foreign students studying in Australia. So, in this study we attempted to find the cost of living and studying in Australia by Nepalese students, source of funding and the role of Nepali banks in providing support to these students. As research participants, students residing in Australia for their higher study were selected through random sampling. A set of questionnaire was prepared by reviewing relevant literature survey. Fifty participants (randomly selected) were contacted through e-mail. Only 16 of them filled up the questionnaire completely and returned (response rate, 32\%). Later on after tabulation of data, two information rich respondents were purposefully selected for detail study. They were regularly contacted through email and through Skype internet chatting was done. Cost of migration, living and study is very high in Australia. Students were found meeting their cost requirements through various sources. Among them family was the initial source of funding and at the later stage seemed to be mitigated their educational and survival expenses through part time job, scholarships and stipends. None of them were found to have education loan as a source of educational funding. Hence the role of bank is not apparent. Provisions of collateral, complex documentation procedures and high interest rate for student loan are the reasons why students are not interested in education loans. Education loan market can be the area where banks can think of investment. Furthermore subsidised rate of interest and easy documentation and repayment system can lure the students to take loans. This can also be worked out with collaboration with government or Educational institution as practised in other parts of world. Further in depth study of similar kinds is recommended.
\end{abstract}

Key words: Education loan, student loan, financing higher education, repayment, role of bank 


\section{INTRODUCTION AND BACKGROUND}

In the last few decades, lots of youths have migrated to foreign land from Nepal for their study. An estimated 20,000 students leave the country annually to pursue their education abroad according to the Ministry of Education, Nepal (NIDS, 2008); however it seems to be the tip of the iceberg as we don't have proper body or commission to look after these issues so exact number of international student migration is un-known. These numbers seem to be increasing with every passing year. In the Fiscal year 2008-09 the Ministry of Education has issued around 25000 no objection letters and the number increased to around 27000 in the year 20092010 (Awasthi, 2067). Again, the number might be still higher because NoObjection letters is not necessary to go to study in most of the universities in India. United Kingdom (UK), United States of America (USA), Australia are the invariably preferred destinations of Nepalese student migrants (Bhattarai, 2009).

According to a report in Kantipur dated $29^{\text {th }}$ Shrawan, 2067 (one of the popular national Dailies in Nepal) the increased outflow of students was accompanied by a huge outflow of funds as well which was estimated to be more than NRs 2000 million (Awasthi, 2067). If we compare it with the total Nepalese education budget of FY 2066-67, it comes out to be more than $40 \%$ of total National budget on education. The total budget allotted for education in 2066-67 was around 4600 million Nepali rupees. In this back drop Nepalese bank can consider to invest in higher education sub-sector. The high potential for investment in education can be substantiated since the transaction of 2000 million NRs is obviously an indication of huge education investment market.

In recent days, Australia has been established as the top destination for Nepalese students. In 2009 alone, 24,579 Nepalese students were enrolled in Australian colleges and universities (Keefe, 2007). According to the latest statistics of the federal Government's Australian Education International (AEI), Nepal currently stands in the $6^{\text {th }}$ position in terms of number of students studying in Australia (Table 1).

Table: 1: International student enrolments - Top 10 nationalities in 2009

\begin{tabular}{llll}
\hline Nationality & Enrolments & \% of total & Growth on $\mathbf{2 0 0 8}$ \\
\hline China & 154,777 & $24.5 \%$ & $18.0 \%$ \\
\hline India & 120,913 & $19.1 \%$ & $25.4 \%$ \\
\hline Republic of Korea & 35,708 & $5.7 \%$ & $1.6 \%$ \\
\hline Thailand & 26,460 & $4.2 \%$ & $19.0 \%$ \\
\hline Nepal & 24,579 & $3.9 \%$ & $36.5 \%$ \\
\hline Vietnam & 23,755 & $3.8 \%$ & $49.9 \%$ \\
\hline Malaysia & 23,103 & $3.7 \%$ & $9.5 \%$ \\
\hline Indonesia & 17,867 & $2.8 \%$ & $11.8 \%$ \\
\hline Brazil & 17,529 & $2.8 \%$ & $10.3 \%$ \\
\hline Saudi Arabia & 12,599 & $2.0 \%$ & $61.8 \%$ \\
\hline Other nationalities & 174,645 & $27.6 \%$ & $8.1 \%$ \\
\hline All nationalities & 631,935 & $100.0 \%$ & $16.8 \%$
\end{tabular}


Figure 1: International Student Enrolments in Australia 1994- 2009

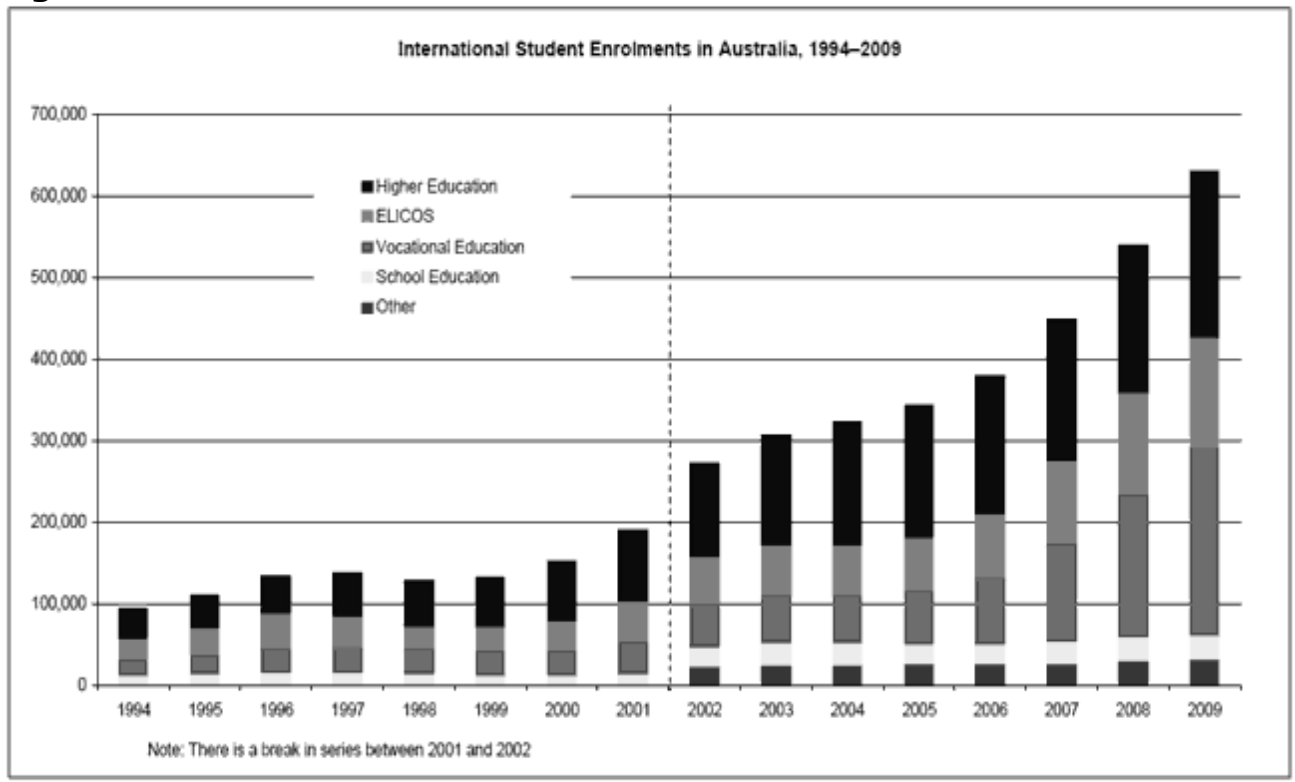

Source: (AEI, 2009)

The growing enrolments of foreign students are in accordance with the strategies of expanding higher education sector in Australia and the federal immigration and citizenship department eased student visa rules in September, 2007 (Keefe, 2007). Foreign students on one hand pay higher tuition fee and on the other contribute to improve the international dimension and global reputation of those schools. This allows expansion of higher education sector in Australia. Here in this study an attempt has been made in finding out the cost of living and financing education in Australia and source of funding education by Nepalese students and role of Nepalese bank on financing their education.

So, in this study we attempt to find the Cost of living and studying in Australia by Nepalese students, source of funding and the role of Nepali bank in providing support to these students. To this end, following research questions were set to meet the objective of this research.

\section{Research questions}

The main purpose of the study was to identify expenditure and source of financing the students have accessed to study in Australia and roles of Nepalese bank in this respect. Thus following were the research questions developed for our study:

- What are the expenses and expenditure for studying in Australia?

- What are the sources of funds for their migration and after their migration to sustain their study in Australia?

- What role have Nepalese Banks played for funding?

\section{METHODOLOGY}

This study was planned to answer the research question mentioned above. During the data collection process it was realised that the questionnaires were not 
sufficient to cover different facets of financing education in Australia by Nepalese students. So, two cases of different natures were chosen to enrich the study. This study is a quantitative study followed by two cases study which is qualitative in nature. So this study is a blending of quantitative and qualitative data. Students who were already in Australia for their further study were selected by random sampling and information was collected from a set of questionnaire prepared through appropriate literature survey. All the participants were contacted through e-mail. First by using social contact, email addresses were collected and the set of questionnaire was forwarded to 50 students (randomly) in Australia. Only 16 of them fill up the questionnaire completely and returned (response rate, 32\%). Later on after the tabulation of data, two respondents were purposefully selected for detail study. The logic and power of purposeful selection is to select information rich cases for in depth study (Patton, 1990, p.169). Since the respondents were the ones who were already abroad, interview was done through internet chatting and Skype and also through mail. At first an email requesting for their time was sent to two of the selected cases and later online interview was done to collect the required information. They were contacted several times, whenever clarification was needed. The respondents were insured that their identity would not be disclosed. The verbal and written consent was taken.

\section{Sampling:}

As our respondent are those who are already abroad it was hard for me to contact the respondent. Thus we used our social capital to get access to the respondents using networks of relations described as springboard by Leeds (1964) (as cited in Sharma, 2009, p.43). We first asked two of our friends who were in Sydney and Melbourne to be our respondents and asked for email addresses of friends from different places in Australia. After getting their email addresses, we e-mailed fifty of them by random sampling. Taylor and Bogdan (1998) write "the basic approach of access to the private settings is the "snowball" technique. Start with one or a small number of people, win their trust and ask them to introduce you to other people" (p.32). Later on, after getting the questionnaire filled and tabulated, two cases who were assessable and information-rich participants were selected.

Among the two cases, one is a 26 years old male (Mr. B. Acharya) who is there for one and half years. He changed his course from Bachelor in Management to Diploma in Cookery and is financing his course by himself. The next is 25 years old female (Ms. H. Karki) who is about to finish her MS degree in science, who has been there for more than two years and has been financing her education through full scholarship.

Later on, to find the provisions for student loan, the related website were surveyed. Similarly, the literature related to student loans were reviewed to carry on the study.

\section{Data Collection:}

A set of questionnaires and an interview were the main tools used for data collection. First, questionnaire was used to collect the students views, Having Analysed their views, two cases (individual having rich information potential) were 
identified and later they were interviewed for which an interview schedule was developed. As they are living abroad, they were interviewed through internet chatting and email. Apart from how they have met their financial requirement for their education, they were also asked what other ways foreigners adopt in financing their education in a foreign country. Quantitative data were analyzed using Excel and for the analysis of qualitative data the interactive model developed by Miles and Huberman (1994) was used which consists of the sequential steps i.e. data organizing, data reduction, data display and data interpretation or description (as cited in Sharma, 2000). Later on, for studying the provisions of Nepalese banks for student loan, related websites were visited.

\section{RESULT AND DISCUSSION}

Out of 50, only 16 respondents filled the questionnaire and returned to the researcher. The response rate was $32 \%$. Out of 16,13 were males and 3 females. The demographic details of participants are presented in Tables 2, 3, 4 and Figures 2,3 and 4.

Table 2: Years spent in Australia by Participants

\begin{tabular}{ll}
\hline Years in Australia & Number of students \\
\hline $1-2$ years & 5 \\
\hline $2-3$ years & 6 \\
\hline $3-4$ years & 0 \\
\hline$>4$ years & 5 \\
\hline
\end{tabular}

Table 3: Participants in different age group

\begin{tabular}{ll}
\hline Age group & Number of students \\
\hline$<20$ years & 1 \\
\hline $20-25$ years & 7 \\
\hline $26-30$ years & 6 \\
\hline $31-35$ years & 2 \\
\hline$>35$ years & 0 \\
\hline
\end{tabular}

Table 4: Participants location from the city centre

\begin{tabular}{ll}
\hline Staying place & Number of students \\
\hline At or nearby city centre & 0 \\
\hline 30 min - 1 hr away & 5 \\
\hline $1-2$ hrs away & 9 \\
\hline$>2$ hrs away & 2 \\
\hline
\end{tabular}

Academic cost or expenditure:

The cost for studying in Australia depends mainly on the type of course being studied. The annual fee paid to the university for the course by the participant ranges from \$ 15000 to $\$ 29000$ (Australian dollar). The mean being \$20131 \pm 4682. Table 5 shows the annual academic expenses of the participants. The diploma and advanced diploma course are bit cheaper than the bachelor course. 
Most of the participants are enrolled in diploma courses followed by Bachelor courses. The diploma courses costs maximum of $\$ 15000-\$ 17000$ a year, according to B. Acharya: "Some courses are even cheaper". So, 38 \% of students have adopted the Diploma courses. They usually pay tuition fee semester wise. Enrolling in Bachelor course on average starts from $\$ 7500$ a semester (at the cheapest university). Number of semesters depends on faculty chosen, e.g., accounting has 6 semesters. A semester consists of 4-5 subjects.

According to Mr. Acharya: "...Majority of the students are enrolled in diploma courses rather than bachelors (in which only handfuls are, considering the number of Nepalese students in Melbourne) because of the financial burden plus the amount of study time required just to pass a subject. $A$ failure of a subject means, you'd need to pay roughly \$1800-2200 to repeat the subject..."

This shows that the students who choose Bachelor degree have to give much time to study and usually don't want to repeat the course as it will be expensive for them. So they choose diploma or advanced diploma courses that are easy and cheap. Most of the students later change the study course. More than $62 \%$ have changed courses of study after coming to Australia.

"The master courses are expensive but usually the MS degree in science and almost PhD degree (almost all subjects) in Australia are funded by some agency or universities or professors...", says Ms. Karki, who is about to complete her MS degree in Physiology. She is like research scholar there and wants to continue PhD in the same subject, if she receives adequate fund.

\section{Figure 2: Participants level of education in Nepal}

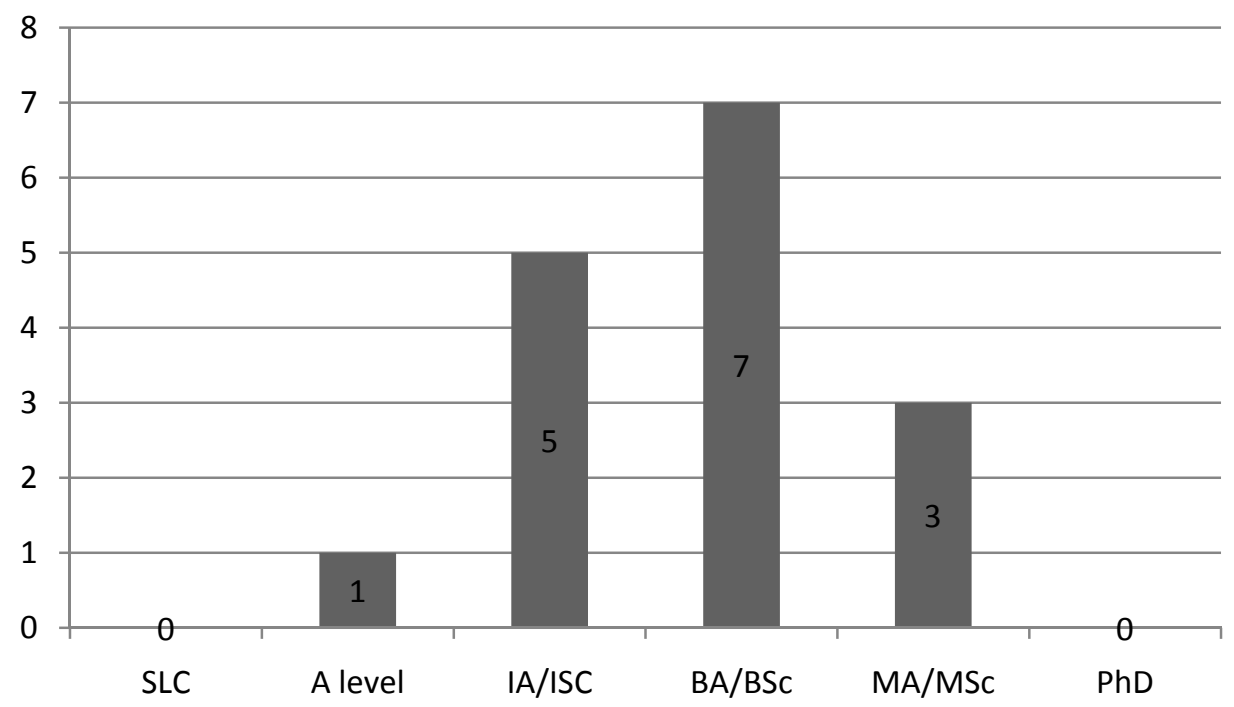




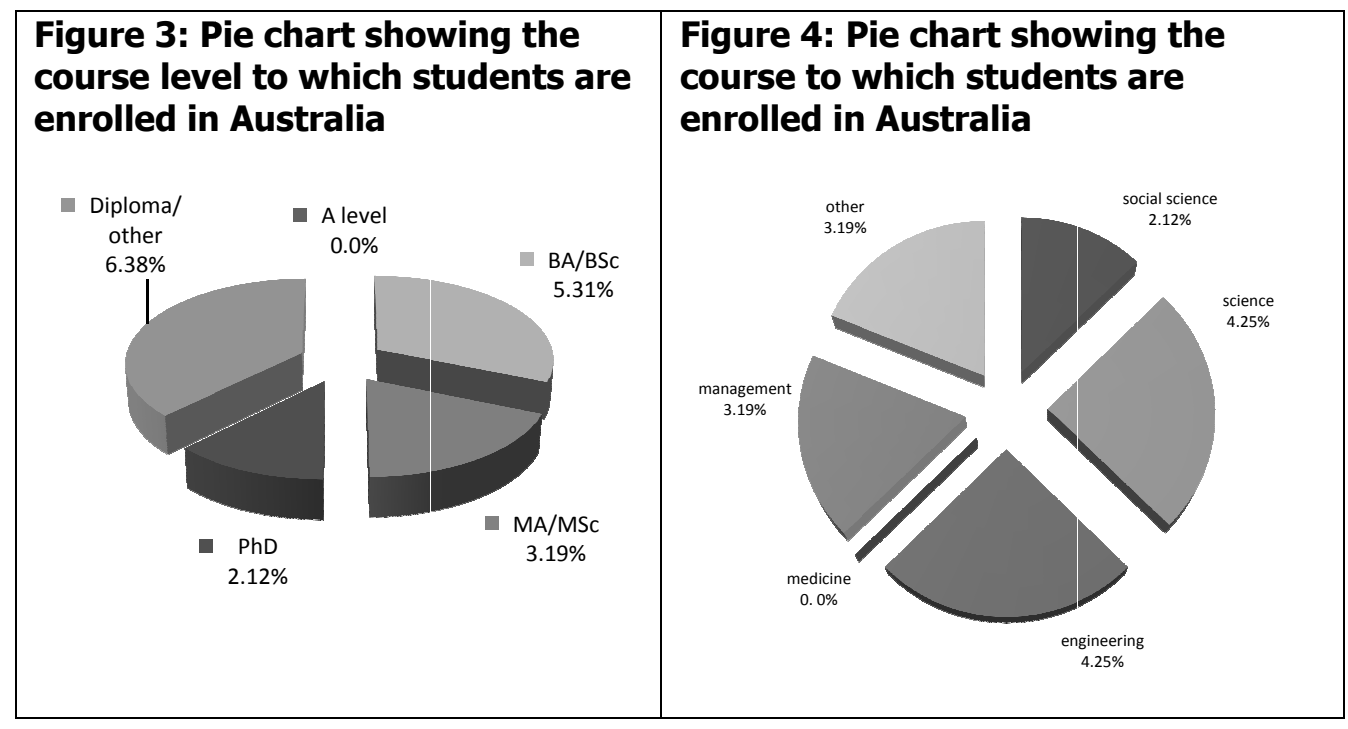

Cost of living in Australia:

Cost of living is high in developed countries. Figure 5 and Table 5 and 6 show the expenditure details of the participants studying in Australia. The mean monthly expenses of the participants come out to be $\$ 1160 \pm 176$. The range is $\$ 800$ 1450. The percentage of total expenses, spent on accommodation, food, travel and others are shown in figure 5 . The rent is very high in Australia. Thirty six percent of total expense goes for rent. Students usually live in groups of 3-5 in a single bedroom house ( 1 bedroom + kitchen + lounge + toilet/bathroom) their share on average would be $\$ 416.25$ a month plus utility bills (electricity, water, gas). The mean ratio of person to room is $3.06 \pm 0.92$. (Mean \pm SD). The transportation cost on average is $\$ 210$ a month.

"The cost may come high as we have to use cabs as per necessity. There is unavailability of public transport after 12.30 A.M on weekdays besides Friday, sometimes we have to use Cabs": Mr. Acharya

The expenses in different headings are summarized in Table 6. Usually, they take cheaper food or cook food at home as it will be much cheaper. "The food outside is costly. One can save expenses by cooking at home": shares Ms. Karki

Cost before entering to Australia/ cost of migration:

In order to migrate to the foreign land, the educational migrants need financial support for expenses to pay tuition fees to get admission in the college, to meet the cost for documentation and visas, logistics and for air fare and settlement. The average cost for migration before they land on Australia (along with sustaining cost for some time in Australia, which they carry with them when they move to Australia) amounts to an average of $4.5 \pm 0.84$ Lakh Nepalese Rupees. It ranges from 3-6 Lakh. Out of 16 respondents, four of them have managed everything by themselves and other 12 respondents have taken help from the educational agencies. On average those students need to spend $1.29 \pm 0.64$ Lakh Nepalese 
Rupees (range 0.5 to 2 Lakh NRs) as commission or service charges to such agencies.

Other expenses:

Other expenses include Health Insurance costs and pocket money. The health service is too expensive and the students usually avoid those costs. Pocket expenses vary from person to person depending on their choices of recreation.

Table 5: Annual Academic expenses (in Aus \$) on different categories

\begin{tabular}{lll}
\hline Categories & Mean amount & SD \\
\hline Annual fee & 20131.25 & 4682.12 \\
\hline Stationery/study material & 335.63 & 99.06
\end{tabular}

SD, standard deviation; 1 Aus \$ = NRs 77 (May 2011)

Table 6: Showing monthly expenses (in Aus \$) on different categories

\begin{tabular}{lll}
\hline Categories & Mean amount & SD \\
\hline Rent & 416.25 & 55.72 \\
\hline Travel & 209.375 & 72.8 \\
\hline Food & 391.875 & 73.41 \\
\hline Others & 142.19 & 38.42 \\
\hline Total & 1159.69 & 176.32 \\
\hline
\end{tabular}

Figure 5: Pie chart showing percentage of total expenditure on different categories

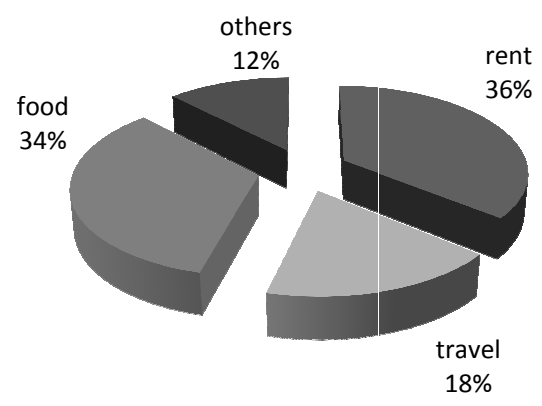

Figure 6: Pie chart showing the job providers of the participants

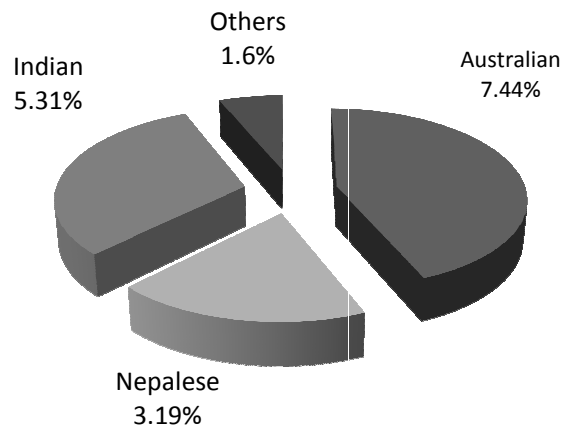

Source of meeting the cost/expenses:

This section discusses the major findings related to the sources of funds for/after migration. In order to migrate to the foreign land and to sustain there, the educational migrants need financial support for expenses such as tuition fees, books, fees, subsistence, stationary etc as mentioned in above section. In this section, the sources of funds under different headings such as family source, part time job, stipends and scholarships are presented. 
Initial Cost and Source:

The cost of moving to Australia and admission cost at the beginning is regarded as the initial cost in this study. Table 7 shows the source for meeting the initial cost of the students. Parents of our participants were the primary source for meeting the initial cost in all the cases. In all the cases of our study, their parents have borne at least some part of their initial costs. Relatives and friends in Australia appeared to be the second common source of meeting the initial cost of our participants. None of the students initial cost was borne by banks.

Table 7: Sources for meeting initial cost of the students

\begin{tabular}{lll}
\hline Source of initial Expense & Percentage & Number of student \\
\hline From family & $100 \%$ & 16 \\
\hline Bank Loan & $0 \%$ & 0 \\
\hline Self & $12.50 \%$ & 2 \\
\hline From relatives/friends in Australia & $37.50 \%$ & 6 \\
\hline Scholarship & $6.25 \%$ & 1 \\
\hline Others & $12.50 \%$ & 2 \\
\hline Total* & $169 \%$ & 27 \\
\hline $\begin{array}{l}* \\
\text { individual }\end{array}$ &
\end{tabular}

Part Time Job:

Since the living and educational costs in developed countries are very high, it is not possible for Nepali to complete their study without working part time. Family cannot provide support fully to cover their study cost. Thus, the students search for part time job in order to build their human capital. In this regard, Mr. Acharya said, "All of the Nepali has to work in order to support their study; In fact, the money I brought from home will cover up to three-four months. I started working in a departmental store after a month or so."

Similar idea was expressed by one of the participant and he said, "I am working at gas station 6 hours 5 days a week to cover my study expenses." Thus it shows that through part time job they could earn some money and with this they could sustain their educational journey (Bontch - Osmolovski, 2007 as cited in Sharma, 2009). As one of the participants mentioned that he worked 6 hrs 5 days a week amounting in total of 30 hours. However, there are laws that do not allow students to work for more than 20 hours a week and students also have to abide by other requirements of Immigration Department. "If they can afford to study in Australia only by working 100 hours a week then I would say they cannot afford to come to Australia," said Linda Laker, Minister-Counsellor for Education, Employment and Workplace Relation of Australian Educational International (AEI) in an interview with the Kathmandu post, who was on a short visit to Nepal from Delhi-based Australian High Commission (Kathmandu Post, June 16, 2008). 
Mr. Acharya in this regard said: "... On average, the hourly pay is $\$ 15$ (this is a decent rate), legally international students are only allowed to work 20 hours a week. If a student chose to work legally here....., it is clear that they would only have enough to live in Australia but will not be able to pay their tuition fees."

The growing attraction of young students from different parts of the world to Australia for higher studies has made job opportunities very competitive and scarce in recent years in Australia (Kathmandu Post, 2008). So, there are many Nepalese, Indians and Pakistanis who provides part-time job to students and pay less, even 810 dollar per hour. In our study too, it was seen that $31 \%$ of the participants work in the enterprises owned by Indians and $19 \%$ in owned by Nepalese (Figure 6). Most of them work in Restaurants or Supermarkets.

Here, It is important to quote a paragraph from the UK based similar study by Bhattarai (2009) which clarify the state of Nepali students in foreign countries: Nepali students are lured to UK because of opportunities for learning and earning. They are usually informed that the immigration rules allow foreign students to work 20 hours per week, minimum wage of at least $\$ 5.80$ per hour can be expected for these hours making them eligible to earn up to $£ 460$ per month. This is enough to cover their living expenses. Many parents count on this before selling their properties to finance tuition, visa and travelling expenses required to a college or university in the UK. It is becoming clear in recent months that these expectations are gradually proving wrong. Responses from the survey reveal that the most of these new students are in difficulties. They have not been able to find jobs and have used up all money they brought with them. They are living in very poor and unacceptable conditions and many are found regretting decisions to come to study here.

The above paragraph speaks a lot and gives the picture of Nepali students in alien land struggling to finance their study in living cost. The cost of living and cost of education is very high with respect to Nepal.

\section{Family and Friend's Support:}

From family in Nepal: All most all (except one) participants enjoyed the support of family in Nepal while moving to Australia for their study. However, the amount and percentage of total cost varies. Few students would have the support (to some part) till they finished their course work. Ms. Karki (our respondent) mentioned that it cost about NRs 3, 00, 000 for her to travel to Australia and she added "I have to take help from my family as I have not saved that much money from my earning in Nepal as a teacher".

From family in Australia itself: Four of the respondents have taken or are taking help from the family staying in Australia. The help would be in the form of paying some amount of tuition fees or it might be in the form of staying with them. One of the two cases, Mr. Acharya is staying with her sister in Melbourne (outskirt). Her sister also supported him to pay his fees for a year. He shares: "Before I came to Australia, I have a (verbal) contract with my sister that she would finance for my 
two semester course and I would pay her back after a year or so. And I did that." He further shared that: "Now, I also share some monthly expenses here at home."

\section{From friends in Australia:}

Two of the respondents shared that their friend there in Australia helps them to migrate to Australia. They helped them financially to get admitted in the University. They paid fee for first semester too. One of the respondents mentioned that: "I stayed for around a month in my friends' apartment, he helped me a lot to find job and apartment. He was the one who paid fees for first semester. I paid back later."

\section{Cost sharing approach:}

As cost of living is very high, 3-5 students share a one-room flat. This will reduce the cost of living. As they share the kitchen and mange it, it also decrease the cost of living. One of the participants is staying with a Nepali family as a paying guest, which is cheaper than staying alone or with others. This also gives sense of security and belongingness. Mr. Acharya confirms this too. He said: "As my sister has bought a house with 3 bed rooms, I stay with them, not only this I have one of my friends with me as my roommate who is a paying guest in my sister's house. ..... This is good for all of us in terms of cost and work sharing at home".

As, Population of Nepalese students is growing annually in Australia (AEI, 2009) and there is opportunity for students to earn while studying and there are also encouragements for some students to get permanent residence and eventually stay in Australia, such way of cost sharing by family members and friends in the name of paying guest is common now a days. In this context of "student earning while studying" Linda Laker from AEI said: "There is nothing wrong in students choosing that as an option," she added: "But from our point of view, we firstly want students because they have to study, not for other reasons." (eKantipur, 2008, June 16).

This shows that the concerned authorities in Australia are worried regarding the intention of foreign students working illegally in Australia. In the name of cost sharing and minimizing cost of living, Nepalese students are losing their reputation in Australia. Just last year, local authorities in Victoria shad raided a house where dozens of Nepali students were living in a "not acceptable" condition (http://www.chautari.org/forums/index.php?showtopic=9937). "We are very much concerned about stories that Nepali students or any other international student for that matter living in accommodation, which we would feel not acceptable for students," Laker said: "It is very important that students understand the costs involved before they come to Australia" (eKantipur, 2008).

Scholarships: Beside family source and part time job, scholarship is one of the sources of funding higher education in Australia. About $35 \%$ participants have got some sort of scholarship. But the amount of scholarship only covers 10 to $25 \%$ of their tuition fees in most of the cases. They love to call it discount in fee. One of the selected cases, Ms. Karki has got $100 \%$ scholarship i.e. she does not have to pay tuition fee. As she has got good IELTS score and GRE score, she got scholarship from the beginning. She is also getting stipend from her professor. She also informed us that many foreign students who are in MS course as research 
students are getting more than 50\% scholarship in tuition fee and they are also supported by professors financially. They are getting stipend as they are also working as research assistant in professor's laboratories. One of the respondent who is doing his bachelor course in management informed that he is getting some support from a professor.

In this regard he explained: "Me along with one of my Australian friends worked for my professor's project. Our professor used to give us some amount and he also recommended the university to grant me scholarship. I am getting 25\% scholarship (scholarship is for students from developing country) due to that recommendation. The scholarship will be continued to next semester too if my performance will be up to the mark."

From the above information we can see that Professor serves as a source of funding for meritous students in Australia and some sort of scholarship is provided to the students from developing countries like Nepal.

Loans:

None of the participants of this study have taken education loan from Bank in this study. But Mr. Acharya and other respondents mentioned that they have taken money from their friends and family members which they have to repay but need not to pay interest on it. In a similar study conducted by Basnyat (2010) one of her participants shared that "I had to get loans from relatives and had to get some more loans from the bank keeping a piece of land as collateral (from a finance company)."

Thus it was found that there are several sources of fund for the students who have moved to Australia for their study for their higher study a major factor for formation of human capital. Among which family source of fund was initial source and later the part time job and scholarship was possible and feasible source of investment in the human capital formation.

\section{Role of Banks of Nepal:}

From this study, it is seen that the role of bank in funding the education of Nepalese student in Australia is not apparent. None of the participants have taken education loan from any Bank. Several Nepalese Banks like, Everest Bank, Nabil Bank, Mega Bank, SBI bank, Bank of Kathmandu (BOK), Kumari Bank, Nepal Bank and many other banks have offered its education loan for higher education. Nabil bank in its website has mentioned that its education loan product is especially designed for students aspiring to pursue further studies abroad. But none of our participants used these facilities. In this regard we interviewed two selected participants. One of them, Ms. Karki even did not try for education loan but next (Mr. Acharya) answered that he tried to gather information regarding education loan but found that its procedures was bit complicated.

He responded as: "I contacted two ( $X$ and $Y$ banks) [authors do not want to disclose the name of banks] but found that it was not exactly the education loan but was like any other loan which one can get loan against collateral and has to 
show parents earning, property and university documents and other documents. Interest rate was also high but not as high as in other types of loans but still not student friendly ..."

\section{Provision of Education loan in Nepalese Banks:}

To get information regarding Nepalese banks provision for education or student loan, we surveyed websites of seven different banks (viz. Everest Bank, Nabil Bank, Mega Bank, SBI bank, Bank of Kathmandu (BOK), Kumari Bank, Nepal Bank) and found that the education loan is provided to the students for higher level education and professional education. The loan varies from 15 Lakh (for study in SAARC countries) by Everest bank to 50 Lakh by Mega bank for student studying abroad. The loan is granted against fixed assets collateral and fixed deposits and government securities. The interest rate varies from $9.00 \%$ per annum (against government securities) by SBI bank to $16 \%$ by Kumari bank; most of other bank interest varies mostly from $12-14 \%$ per annum. The service charge, loan commitment fee, documentation fee and all cost varies from $1-2 \%$ of the loan amount.

The researchers after survey of different bank's websites agreed with our participant's view that the education loan do not differ from other loans in terms of facilities and documentation but the special provision of moratorium period from 1 year to 5 years is there in education loan which is not provisioned for other types of loans. All the documentation procedure and provision of collateral are time consuming and complicated and is not student friendly so it may be the reason why the education loan has not been used by many of the students. Rani (2002), in her paper mentioned that such student loans operated by commercial bank as cost recovery approach will only exacerbate inequality in society. The basic concept of student loans is to encourage people invest in their own tertiary education, especially for needy students with low financial status. Student's loans without considering the low-income group may produce regressive effect in the society. Hence, an alternative student loan scheme specifically for weaker section should be worked out. She further recommend that such programme or provision should be flexible enough to suit students requirements, which may involve government guaranteed loans, subsidised interest rates, liberal terms of payments, waivers for those students with less future incomes etc (Rani, 2002).

\section{Student loan provision and scenario in other parts of world:}

The rationale for student loans derives from the notion that people invest in their own tertiary education. Loan for higher education is as investment because it is a borrowing now to secure a future prospect for better income and greater return over time is a natural expectation (Andrews, 2005). In 2002, P. Geetha Rani in NIEPA's occasional paper reported that student loans are in operation in more than 80 nations. It can be speculated that this number is still higher these years.

In Canada, the Canada student loan program is popular. Similarly Sweden, Denmark and Norway have state agencies for providing student loans. In Norway there is a student loan bank to provide loans to students. In Japan there is a Japanese scholarship foundation which provides student loans (Woodhall, 1987). In 
the united states there are three student loan programmes operated by commercial banks, individual universities and private agencies, but with government guarantee and interest subsidies. National Defence student loan program later named as National Direct student Loan Programme (NDSLP, established in 1958), guaranteed student Loan Program (GSLP, established in 1965) and Parent loans to undergraduate students (Plus, established in 1981) are popular in US. Borrowers have to pay $5 \%$ interest in NDSLP loans and $9 \%$ in GSLP loans (Woodhall, 1987). Several countries including have introduced income contingent student loans. Countries like Australia (Higher education loan program popularly known as HELP) and New Zealand have provision of student loan for seven years of study (Australian Government, 2009; Andrews, 2005). In both the countries the repayment system is student friendly and income contingent. The repayment commences when borrower reaches a certain income threshold. The interest rate is usually base rate + CPI (consumer price index which is reviewed per year). The literature shows that the interest rate in 2005 was $(5 \%+2 \%)$ i.e. $7 \%$ (Andrews, 2005).

In India, the National Loans Scholarship (NLS) scheme is popular and in operation since 1963 with focus on access and equity (Rani, 2002). But Tilak (1992) argued that student loan should be judged more in terms of generating finances for higher education rather than simply as a measure to improve access and equity in higher education. Rani (2002) in her paper also focuses on the trend of student loan throughout the world in the past century. She observed a major shift from the choice of administering agency of student loan from Government/agency to institution/ university to commercial bank and private banks. She further mentioned that there is also gradual shift from regime of interest free loans to subsidised interest on student loans to even equal or higher rates than other sector.

In our country, it seems that we are almost at the recent trend (loan without subsidised rate) without practicing much of older trends of student loan. Students and parents are compelled to finance higher education through loans at higher rate of interest. Such Student loans operated by commercial banks as cost recovery approach will only exacerbate inequality in society. Student's loans without considering the low-income group may produce regressive effect in the society, which is very much harmful for developing countries like ours. So, banks either with collaboration with government or educational institution should think of providing loan in subsidised rate to the students as practised in other parts of the world. Or they should take a lead in the name of corporate social responsibility (CSR) in the development of education sector and get support from government in other ways.

\section{CONCLUSION}

Cost of living and study is very high in developed countries like Australia. It is hard for Nepali to sustain in those countries so people use various sources of funds to finance their studies and subsistence in those countries. Even the cost of migration is high. Family bore the travel, logistics and other initial expenses to send their children to Australia and to sustain there for few months. Some get support from family members or friends in Australia in the beginning phase was another way out. 
Part time job and even stipends and scholarships were other sources for financing their higher education in Australia.

This study showed that none of the participants of our study used any sort of loan for education. The role of Nepali bank in this regard was nil. We found that the provision of collateral, complex documentation procedures and high interest rate are not student friendly. This is one of the reasons why students are not interested in taking education loan. The researcher also agrees that Moratorium period alone is not enough to call a loan as student or education loan.

As, facts and figures showed that the education loan market is alone more than 2000 million per year, so this can be the area where banks can think of investment. This is also a sector through which the bank can show their corporate social responsibility (CSR) and get support from government in other ways. Furthermore subsidised rate of interest and easy documentation and repayment system can lure the students to take loans. This can also be worked out in collaboration with government or educational institution as practised in other part of the world. Further in depth study of similar kinds is needed to gather more information and other possibilities for financing higher education through student loans.

\section{ACKNOWLEDGEMENTS}

This research is partially funded by Research Grant [NBA/BPC RG \#1(A)] provided to Kshitiz Upadhyay-Dhungel, M.Phil Student, KUSOED by Banking promotion Committee, Nepal Bankers Association (BPA/NBA), Kamaladi, Kathmandu, Nepal. Authors also take this opportunity to thank SRIAC-Nepal and Dean of school of education KU and KUSOED members for continuous support to carry out this study.

\section{REFERENCES}

Andrews G. (2005). Student loans in Australia and New Zealand- a summary comparison. Briefing Papers 14, Education Forum, New Zealand. As assessed from www.educationforum.org.nz

Australian Education International (AEI). (2009). 2009 Annual International Student Statistics. Author.

http://www.aei.gov.au/AEI/Statistics/StudsentEnrolmentAndVisaStatistics/2 009/2009_Annual.htm\#enrolments

Australian Government. (2009). Transforming Australia's Higher Education System. Attorney-General's Department, Commonwealth of Australia.

Awasthi G. (2067, Shrawan 29). Padna ko Lagi 20 arba bahiriyo. Kantipur. p. 3.

Basnyat, M. (2010). A study on causes of international migration by Nepalese students. Dummy thesis. Kathmandu University .Unpublished.

Bhattarai, K.(2009). Problems and Prospects of Nepalese Students in UK: Brain Drain, Immigration or Global Network? Business School, University of Hull Cottingham Road, HU6 7RX.

http://www.chautari.org/forums/index.php?showtopic $=9937$

Kathmandu Post, June 16, 2008. Kathmandu, Nepal: Author. Retrieved from www.ekantipur.com 
Keefe B. O. (2007, Nov 18). Huge increase in Nepalese students. The Australian. As retreived from http://www.theaustralian.com.au/higher-education/hugeincrease-in-nepalese-students/story-e6frgcjx-1111114904963

Nathalie W. (2008). Education, Gender and migration. Population Studies Center, University of Michigan .

Nepal Institute of Development Studies (NIDS). (2008). Nepal migration year book 2008. Kathmandu: Author.

Nepal Institute of Development Studies (NIDS). (2008). Nepal migration year book 2008. Kathmandu: Author.

Patton, M. Q. (1990). Qualitative evaluation and research methods (2 ${ }^{\text {nd }}$ ed.). London: Sage Publication.

Rani, P. G. (2002). Financing Higher Education in India in the Post Reform Period: Focus on Access and Equity. NIEPA Occasional Paper No. 31, NIEPA, New Delhi.

Sharma, C. L. (2009). A study on the causes of educational migration in Nepal. Unpublished M.Phil. Dissertation, Kathmandu University, Lalitpur, Nepal.

Tilak, J.B.G. (1992). Student loans in financing higher education in India. Higher Education 23: 389-404.

Woodhall, M. (1987). Student Loans. In G. Psacharopoulas (ed.). Economics of Education: Research and studies. Pergamon press, England.

Websites of different Nepali banks consulted on May 2, 2011 for information on student loan:

- $\quad$ http://www.kumaribank.com/News/interest-rate-loans.html

- http://www.siddharthabank.com/loan_service.php http://www.everestbankltd.com/loan/retail/education_loan.html

- $\quad$ http://www.nepalsbi.com.np/education.php

- http://www.megabanknepal.com/product.php?cms=mega_education_loan\& $\mathrm{tm}=2 \& \mathrm{mid}=36$

- $\quad$ http://www.bok.com.np/productnservice/loans/retail/education.php

- $\quad$ http://www.Nabilbank.com 


\section{ANNEX}

\section{Questionnaire}

Declaration: Objective of this study is to find out the cost and funding of education by Nepalese Students in Australia and role of bank in Nepal. Answers provided are for academic purpose and will be kept strictly confidential. Thank you.

Please answer the right choice with tick $(\sqrt{ })$ or highlight the right answer

1. How long has been since you come to the Australia?

a. one to two year ( ) b. two- three year( ) c. Three -four years( ) d. More than four years ( )

2. Gender: a. Male () b. Female ( )

3. Age: a. below 20 ( ) b. 20-25 ( ) c. 25-30 ( ) d. 30-35 ( ) e. above 35 ( )

4. Education in Nepal: a. SLC ( ) b. A level ( ) c. IA/ISc ( ) d. BA/BSC ( ) e. MA/MSc ( ) f. PhD

5. Are you studying in Australia? a. Yes ( ) b. no ( )

6. Level of study in AUSTRALIA, Now?

7 Subject:
a. A-level ( ) b. BA/BSc ( ) c. MA/MSc ( ) d. PhD ( ) e. others

a. Social Science ( ) b. Science C. engineering ( ) D. Medicine ( ) E. Management ( ) f. others:

8. Have you changed the course or university after you came to Australia: Yes / No

9. Where do you live in Australia: Name of city:

a. centre of city or nearby b. 30 minutes to 1 hours away from city centre c. 1-2 hrs away d. more than 2 hours away

10. Your average monthly expenses (nearest Australian dollar) Rent b. Travel c. Food d. Other e. Total

11. What is the amount you spent on coming to Australia (Nepalese amount)? (cost includes, documents, visa, agent, preparation and so on) a. Total cost: $\quad$ if through agent how much to agent:

12. Annual Tuition expenses (fee only) in Aus dollar):

13. Stationery/ textbook/ teaching material and other expenses (monthly in aus dollar):

14. Do you do any work/job? a. Yes ( ) b. no ( )

15. Employer: a. AUSTRALIAN Company ( ) b. Nepalese in AUSTRALIA ( ) c. Indian ( ) d. Other ( )

16. Do you drive? Yes ( ) b. no ( )

17: Any scholarships or other way of funding you are using:

Yes/ No (please mention amount or percent or any other details):

18: Do you know any other way of funding that your Nepalese friends are using?

If yes please give bit detail

19. How many of you are sharing your flat? :

20. Ratio of person to room:

21. How do you mange the initial cost of education (fee) and migration (while moving) to Australia:
a. From family
b. Bank Loan c. self
d. from friends/relatives in Australia
e. scholarship f. others

22. Briefly write how do you mange the expenses of your education and living in Australia from the day you land there. (Please elaborate)

23. If you took loan from bank than mention which bank you preferred and mention the procedure and detail of loan and repayment module of the education loan

(Any other things or suggestion that you want to give which above questionnaire has not covered) 